\title{
Demobilizing Antibiotic-Resistant Bacteria and Antibiotic Resistance Genes by Electrochemical Technology: New Insights
}

\author{
Djamel Ghernaout ${ }^{1,2}$ \\ ${ }^{1}$ Chemical Engineering Department, College of Engineering, University of Ha'il, Ha'il, Saudi Arabia \\ ${ }^{2}$ Chemical Engineering Department, Faculty of Engineering, University of Blida, Blida, Algeria \\ Email:djamel_andalus@hotmail.com
}

How to cite this paper: Ghernaout, D. (2020) Demobilizing Antibiotic-Resistant Bacteria and Antibiotic Resistance Genes by Electrochemical Technology: New Insights. Open Access Library Journal, 7: e6685. https://doi.org/10.4236/oalib.1106685

Received: August 3, 2020

Accepted: August 23, 2020

Published: August 26, 2020

Copyright () 2020 by author(s) and Open Access Library Inc.

This work is licensed under the Creative Commons Attribution International License (CC BY 4.0).

http://creativecommons.org/licenses/by/4.0/

\begin{abstract}
Taking into account its merits in terms of high efficiency and low energy consumption, electrochemical (EC) technology especially bioelectrochemical system (BES) has been applied largely in reducing different antibiotics from wastewater. BES averts the spread of antibiotic resistance genes (ARGs) via forming less quantity of sludge compared with wastewater treatment plants. Nevertheless, transmembrane permeability and membrane potential could be influenced by the electrical stimulation, conducting to augmentations in the antibiotic-resistant bacteria (ARB) and ARGs in BES. This work discusses the utilization of EC technology especially BES for antibiotic reduction and the fate of ARB and ARGs in such systems. BES can effectively remove antibiotics. Nevertheless, low electric current promotes vertical and horizontal ARGs transfer during the treatment of antibiotics in BES. ARB and ARGs could be inhibited by a higher electric current. Questions regarding the potential role of BES in antibiotic removal and the consequent fate of ARGs and ARB in wastewater are presented. Further research is needed to elucidate the primary ARG transfer mechanism and to fully understand the advantages of BESs.
\end{abstract}

\section{Subject Areas}

Chemical Engineering \& Technology, Electrochemistry

\section{Keywords}

Antibiotic-Resistant Bacteria (ARB), Antibiotic Resistant Genes (ARGs), Bioelectrochemical System (BES), Disinfection, Electrochemical (EC) Technology 


\section{Introduction}

The immoderate utilization of multiple antibiotics conducted to the extensive diffusion of antibiotic-resistant bacteria (ARB) and antibiotic resistance genes (ARGs) in numerous environment matrices like water, sludge [1], soil [2], sediment, etc. [3] [4] [5] [6]. Such a resistance decreases the effectiveness of antibiotics in dealing with infectious diseases, which provokes more than 23,000 deaths per year in the U.S., nearly 25,000 deaths per year in Europe, and even more in less-developed countries [7] [8] [9]. It turned into a worldwide problem for human and animal health [10]. The antibiotic resistance could be diffused by sharing ARGs among microorganisms through horizontal gene transfer (HGT) [11]. Plasmids, integrons, and transposons are the mobile genetic elements frequently implied in the ARG sharing phenomena [11]. In nature, ARGs could remain even after the bacteria are dead [12]. Both intracellular and extracellular ARGs are all set to adapt to novel hosts [13]. The effluents from wastewater treatment plants (WWTPs) and livestock production, frequently with elevated levels of ARGs, are regarded to be important sources of ARB and ARGs in nature [4] [14] [15].

The traditional disinfection techniques (e.g., chlorination [16] [17] [18], UV irradiation [19] [20] [21], and ozonation [22]) in water and wastewater treatment [23] [24] [25] have been found efficient in demobilizing ARB effectively [3] [11] [26]. Nevertheless, most of the ARGs endured even when the ARB are fully demobilized during the disinfection techniques [12] [27] [28]. Rather than all of the time, the disinfection technologies could demolish bacterial deoxyribonucleic acid (DNA) or the cellular structure [29] [30] [31]; however, ARGs could remain in the cell debris and the extracellular ARGs are still causing continuing danger [32] [33] [34]. Lately, techniques for eliminating intracellular ARGs have been to a great degree studied comprising enhanced disinfection [35] [36] [37], constructed wetland [38] [39] [40], and advanced oxidation process (AOPs) [3] [41] [42] [43]. Zhang et al. [44] illustrated a positive relationship between the demobilization of $\mathrm{ARG}$ and the $\mathrm{Cl}_{2}$ injection and residence period; further, they proved that consecutive UV/chlorination [45] [46] [47] could ameliorate demobilization considerably. To reduce both ARB and ARGs efficiently, Oh et al. [48] found that an injection of $\mathrm{Cl}_{2}$ as high as $30 \mathrm{mg} / \mathrm{L}$ or an injection of $3 \mathrm{mg} / \mathrm{L} \mathrm{O}_{3}$ is needed. As the dose of UV irradiation augmented, the abundance of ARGs reduced exponentially [49]. Elevated doses of UV irradiation ( $>10$ $\mathrm{mJ} / \mathrm{cm}^{2}$ ) reduced $\mathrm{ARB}$ and ARGs greatly but considerably augmented the frequency of ARGs transfer together for the higher pressure [50]. Constructed wetlands, particularly those possessing a surface flow pattern, have demonstrated acceptable ARGs removal performances; however, the danger of augmented ARGs transfer still endured [51] [52] [53]. For that reason, novel substitutional methods with elevated reduction performance and low hazard of ARGs transfer are highly required [54] [55] [56]. Lately, AOPs (like Fenton reaction [57], $\mathrm{TiO}_{2}$ photocatalysis, and $\mathrm{UV} / \mathrm{H}_{2} \mathrm{O}_{2}$ [19]) have demonstrated elevated capacity to de- 
mobilize ARB and ARGs [19] [20] [57]. In the Fenton treatment and $\mathrm{UV} / \mathrm{H}_{2} \mathrm{O}_{2}$ process, the hydroxyl radicals could reduce ARGs efficaciously (2.3 - 3.8 logs of decrease) and the Fenton treatment achieved better than $\mathrm{UV} / \mathrm{H}_{2} \mathrm{O}_{2}$ process [58] [59]. Guo et al. [60] proved that photocatalysis by $\mathrm{TiO}_{2}$ has the potential to decrease ARB by 4.5 - 5.8 logs and ARGs by 4.7 - 5.8 logs. For their elevated reduction performance, AOPs are encouraging manners for decreasing $A R B$ and ARGs [61] [62] [63]. However, there are still some gaps in expertise [64] [65] [66]. As an illustration, even if electrochemical (EC) disinfection has been largely employed in killing different bacteria [67] [68] [69], viruses [70] [71] [72], and microalgae [67] [73] [74], its capability in reducing ARGs has not been explored pointedly [75] [76] [77]. Moreover, all the previous researches have concentrated on eliminating intracellular ARGs; however, there is no data about reducing extracellular ARGs performances.

This work discusses the inactivation of ARB and ARGs by EC oxidation/electroFenton process. Further, it compares electro-Fenton and photo Fenton like process UV-C/ $\mathrm{H}_{2} \mathrm{O}_{2} /$ IDS-Cu method with other AOPs techniques. A special focus is accorded to decreased Klebsiella michiganensis strain LH-2 viability and corresponding ARG abundance in bioelectrochemical reactors (BERs). The fate of ARGs during bioelectrochemical treatment of high-salinity pharmaceutical wastewater is discussed. Finally, dares and prospects for bioelectrochemical systems (BESs) are reviewed.

\section{Inactivation of Antibiotic-Resistant Bacteria (ARB) and Antibiotic Resistance Genes (ARGs) by Electrochemical (EC) Oxidation/Electro-Fenton Process}

Recently, Chen et al. [3] assessed the capability of EC oxidation and electro-Fenton method as substitutional treatment processes for demobilizing ARB and ARGs in both intracellular and extracellular forms. They proved that EC oxidation technique was efficacious in dealing with chosen ARB; however, not in treating intracellular ARGs or extracellular ARGs. The electro-Fenton method was more performant in eliminating both intracellular and extracellular ARGs. Reducing efficacy following $120 \mathrm{~min}$ of electro-Fenton application under 21.42 $\mathrm{mA} / \mathrm{cm}^{2}$ was $3.8 \operatorname{logs}$ for intracellular tet $\mathrm{A}, 4.1$ logs for intracellular ampC, 5.2 logs for extracellular tet $\mathrm{A}$ and $4.8 \operatorname{logs}$ for extracellular $\operatorname{ampC} \mathrm{C}$, respectively in the

occurrence of $1.0 \mathrm{mmol} / \mathrm{L} \mathrm{Fe}^{2+}$ (Figure 1). They concluded that EC oxidation was a performant disinfection technology for $\mathrm{ARB}$ and the electro-Fenton process is an encouraging process for eliminating both intracellular and extracellular ARGs in wastewater.

\section{Comparing Electro-Fenton and Photo Fenton Like Process $\mathrm{UV}-\mathrm{C} / \mathrm{H}_{2} \mathrm{O}_{2} / \mathrm{IDS}-\mathrm{Cu}$ Method with Other AOPs Techniques}

AOPs are extremely performant in demobilizing ARGs more than traditional disinfection techniques (e.g., chlorination, UV, and ozonation). Zhang et al. [58] 


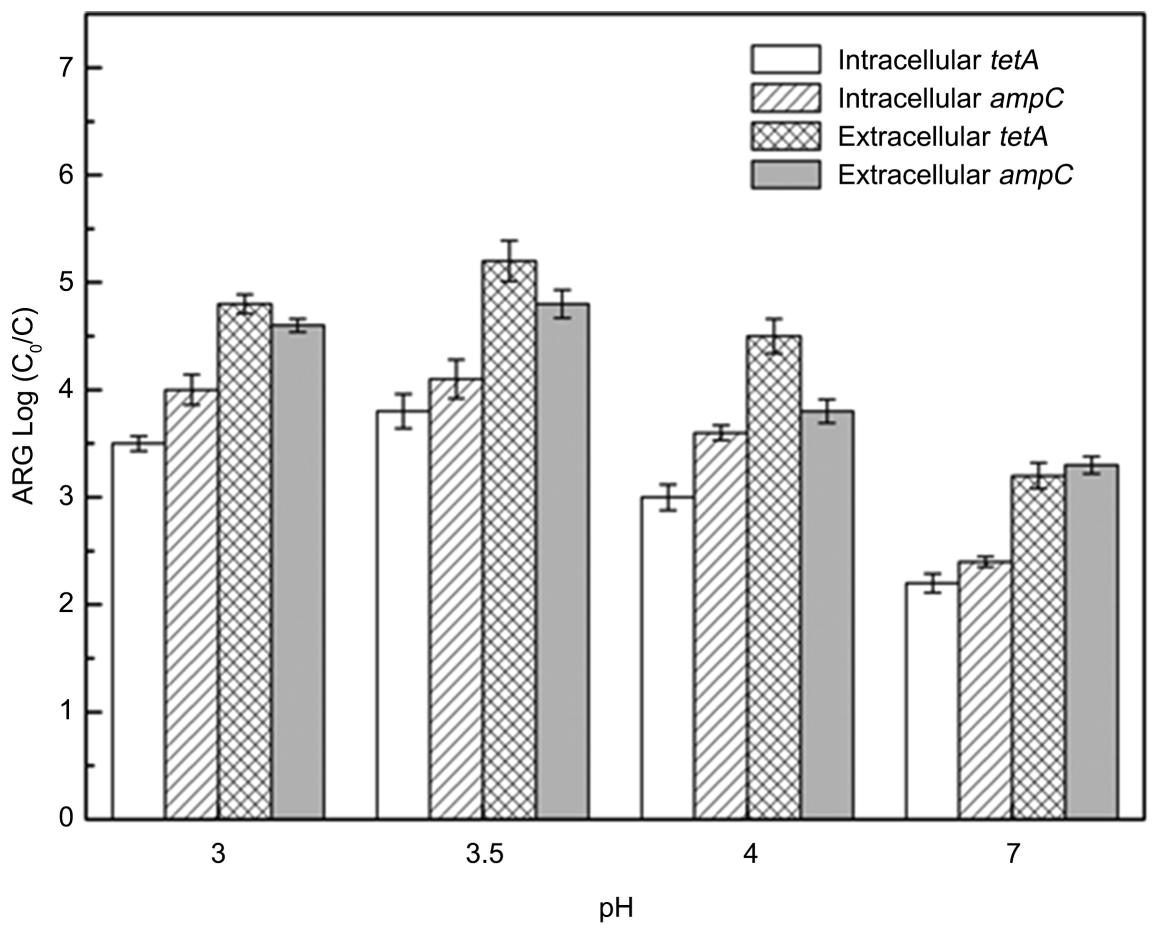

Figure 1. Effect of initial $\mathrm{pH}$ on the removal of ARGs after $120 \mathrm{~min}$ of electro-Fenton treatment (current density: $21.42 \mathrm{~mA} / \mathrm{cm}^{2} ; \mathrm{Fe}^{2+}$ concentration: $1.0 \mathrm{mmol} / \mathrm{L}$ ) [3].

illustrated that the maximum reduction of ARGs by the $\mathrm{UV} / \mathrm{H}_{2} \mathrm{O}_{2}$ method and the Fenton technique was $2.8-3.5$ logs and $2.6-3.8$ logs, respectively. Whilst Guo et al. [60] noted that a reduction of 5.2 logs intracellular mecA, $3.3 \operatorname{logs}$ extracellular mecA, 4.4 logs intracellular ampC and 2.6 logs extracellular ampC were attained by $\mathrm{UV} / \mathrm{H}_{2} \mathrm{O}_{2} / \mathrm{TiO}_{2}$ photocatalysis (Table 1 ). The electro-Fenton method appears as an encouraging method for eliminating both intracellular and extracellular ARGs in wastewater.

Recently, Di Cesare et al. [78] juxtaposed the performance of a novel AOP, namely the photo Fenton like process UV-C/ $\mathrm{H}_{2} \mathrm{O}_{2} / \mathrm{IDS}-\mathrm{Cu}$, in eliminating determinants of antibiotic resistance and pathogenic bacteria to a consolidated AOP (namely UV-C/ $\mathrm{H}_{2} \mathrm{O}_{2}$ ) in a secondary treated municipal wastewater. Tests were realized in both, human pathogens favorable conditions (HPC, in rich medium and $37^{\circ} \mathrm{C}$ ) and in environmental mimicking conditions (EMC, original wastewater and $20^{\circ} \mathrm{C}$ ). UV-C $/ \mathrm{H}_{2} \mathrm{O}_{2} / \mathrm{IDS}$ - $\mathrm{Cu}$ method resulted to be more efficient than the UV-C/ $\mathrm{H}_{2} \mathrm{O}^{2}$ in demobilizing bacterial cells in the EMC post-treatment regrowth tests. Both AOPs were efficaciously abating potential human pathogenic bacteria and ARGs in the HPC regrowth tests, even if such a tendency cannot be detected in the measurements taken immediately following the disinfection. In comparison with the UV-C/ $\mathrm{H}_{2} \mathrm{O}_{2}$, the UV-C/ $\mathrm{H}_{2} \mathrm{O}_{2} / \mathrm{IDS}-\mathrm{Cu}$ technique did not clearly provide considerable amelioration in decreasing the tried parameters in the wastewater effluent. By estimating the findings of the regrowth trials it was however easy to extrapolate more complex tendencies, suggesting opposite performances that are visible only after a few hours. Di Cesare et al. [78] 
Table 1. Juxtaposing electro-Fenton with other AOPs techniques for eliminating ARGs [3].

\begin{tabular}{|c|c|c|c|}
\hline Technique & Optimal conditions & Reduction of targeted ARGs & Reference \\
\hline Electro-Fenton & $\begin{array}{c}\text { Current density: } 21.42 \mathrm{~mA} / \mathrm{cm}^{2} \\
\mathrm{Fe}^{2+}: 1.0 \mathrm{mmol} / \mathrm{L} ; \mathrm{pH}: 3.5 ; \text { time: } 2 \mathrm{~h}\end{array}$ & $\begin{array}{l}3.8 \text { - } 4.1 \text { logs (intracellular); } \\
4.8 \text { - } 5.2 \text { logs (extracellular) }\end{array}$ & [3] \\
\hline$U V / H_{2} O_{2}$ & $\begin{array}{c}\mathrm{H}_{2} \mathrm{O}_{2}: 0.01 \mathrm{~mol} / \mathrm{L} ; \mathrm{pH}: 3.5 ; \\
\text { time: } 30 \mathrm{~min} .\end{array}$ & $2.8-3.5 \operatorname{logs}$ (intracellular) & {$[58]$} \\
\hline Fenton & $\begin{array}{c}\mathrm{Fe}^{2+} / \mathrm{H}_{2} \mathrm{O}_{2}(\mathrm{~mol}): 0.1 \\
\mathrm{H}_{2} \mathrm{O}_{2}: 0.01 \mathrm{~mol} / \mathrm{L} ; \mathrm{pH}: 3.0 ; \text { time: } 2 \mathrm{~h} .\end{array}$ & $2.6-3.8 \operatorname{logs}$ (intracellular) & [58] \\
\hline $\begin{array}{l}\mathrm{UVIH}_{2} \mathrm{O}_{2} / \mathrm{TiO}_{2} \\
\text { photocatalysis }\end{array}$ & $\begin{array}{l}\text { UV fluence dose: } 120 \mathrm{~mJ} / \mathrm{cm}^{2} \text {; } \\
\qquad \mathrm{H}_{2} \mathrm{O}_{2}: 0.1 \mathrm{~mol} / \mathrm{L}\end{array}$ & $\begin{array}{l}4.4-5.2 \text { logs (intracellular); } \\
2.6-3.3 \text { logs (extracellular) }\end{array}$ & [60] \\
\hline
\end{tabular}

presented a detailed discussion of the elimination performance of microbiological/genetic parameters for the UV-C/ $\mathrm{H}_{2} \mathrm{O}_{2} / \mathrm{IDS}-\mathrm{Cu}$ technique, calling for technical adjustments for this extremely encouraging method. Moreover, Di Cesare et al. [78] comprehensibly proved the inadequacy of currently applied methodologies in the estimation of specific parameters (e.g. determinants of antibiotic resistance and pathogenic bacteria) in wastewater.

\section{Decreased Klebsiella michiganensis Strain LH-2 Viability and Corresponding Antibiotic Resistance Gene (ARG) Abundance in Bioelectrochemical Reactors (BERs)}

Researchers demonstrated that the electrolytic stimulation method in a bioelectrochemical reactor (BER) could accelerate the growth of sulfadiazine (SDZ) antibiotic-resistant bacteria (ARB) in nutrient broth medium [79]. Nevertheless, the effect of various medium nutrient richness on the fate of ARB and the relative abundance of their corresponding ARGs in such technique is little known. Precisely, it is not known if the fate of ARB in minimal nutrition simulated wastewater is the same as in nutrient broth under electrolytic stimulation [79]. Thus, Li et al. [79] compared nutrient broth medium and the simulated wastewater to determine differences in the relative abundance of Klebsiella michiganensis LH-2 ARGs in response to the electrolytic stimulation process, as well as the fate of the strain in simulated wastewater. They obtained lower biomass, specific growth rates, and viable bacterial counts in response to the application of increasing current to simulated wastewater medium (Figure 2). In addition, the percentage of ARB lethality, which was reflected by flow cytometry analysis, augmented with the current in the medium. An important positive correlation of sul genes and intI gene relative abundance versus current was also noted in nutrient broth. Nevertheless, an important negative correlation was noted in simulated wastewater due to the higher metabolic burden, which may have conducted to reduced ARB viability. The reduction in ARGs abundance was responsible for reduced strain tolerance to SDZ in simulated wastewater. Minimal nutrition simulated wastewater may decrease ARB and ARGs propagation in BER. 


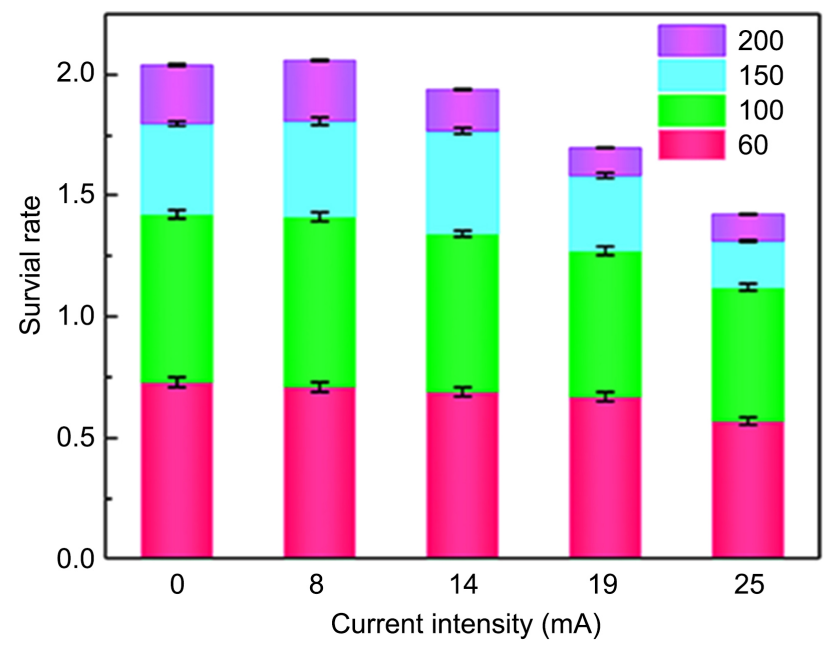

(a)

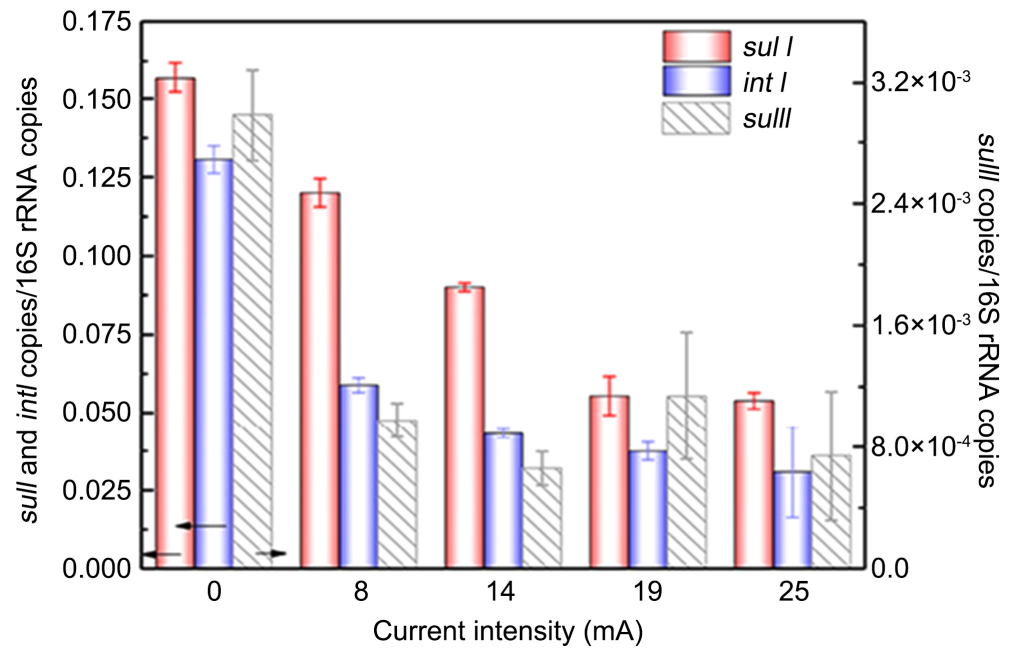

(b)

Figure 2. Effects of different current intensities on changes of $K$. michiganensis LH-2 resistance characteristic to sulfadiazine. (a) Survival rate of the strain exposed to different concentration sulfadiazine in simulated wastewater medium without glucose after electrolytic stimulation. (b) Sul genes and intI gene relative abundance change of $K$. michiganensis LH-2 in simulated wastewater medium without glucose after electrolytic stimulation [79].

\section{The Fate of Antibiotic Resistance Genes (ARGs) during Bioelectrochemical Treatment of High-Salinity Pharmaceutical Wastewater}

Pharmaceutical wastewaters carrying antibiotics and high salinity could harm conventional biological treatment and conduct to the spread of ARGs [80] [81] [82]. Bioelectrochemical system (BES) is an encouraging method for treating pharmaceutical wastewater. Nevertheless, the fate of ARGs in BES and their correlations with microbial communities and horizontal genes transfer stay unknown. Guo et al. [83] examined the response of ARGs to bioelectrochemical treatment of chloramphenicol (CAP) wastewater and their potential hosts below various salinities. Three ARGs encoding efflux pump (cmlA, floR and tetC), one 
class 1 integron integrase encoding gene (int $I 1$ ), and sull gene (associate with int I1) were followed. Correlation analysis between the microbial community and ARGs showed that the abundances of potential hosts of ARGs were greatly influenced by salinity, which further determined the modification in ARGs abundances below diverse salinities. There were no important correlations between ARGs and int $I 1$, showing that horizontal gene transfer was not related to the considerable modifications in ARGs (Figure 3). Further, the CAP reduction performance was improved under a moderate salinity, attributed to the altered microbial community driven by salinity. Consequently, microbial community shift is the major factor for the changes of ARGs and CAP removal efficiency in BES under different salinities. Guo et al. [83] suggested novel insights on the mechanisms underlying the change of ARGs in BES treating high-salinity pharmaceutical wastewater.

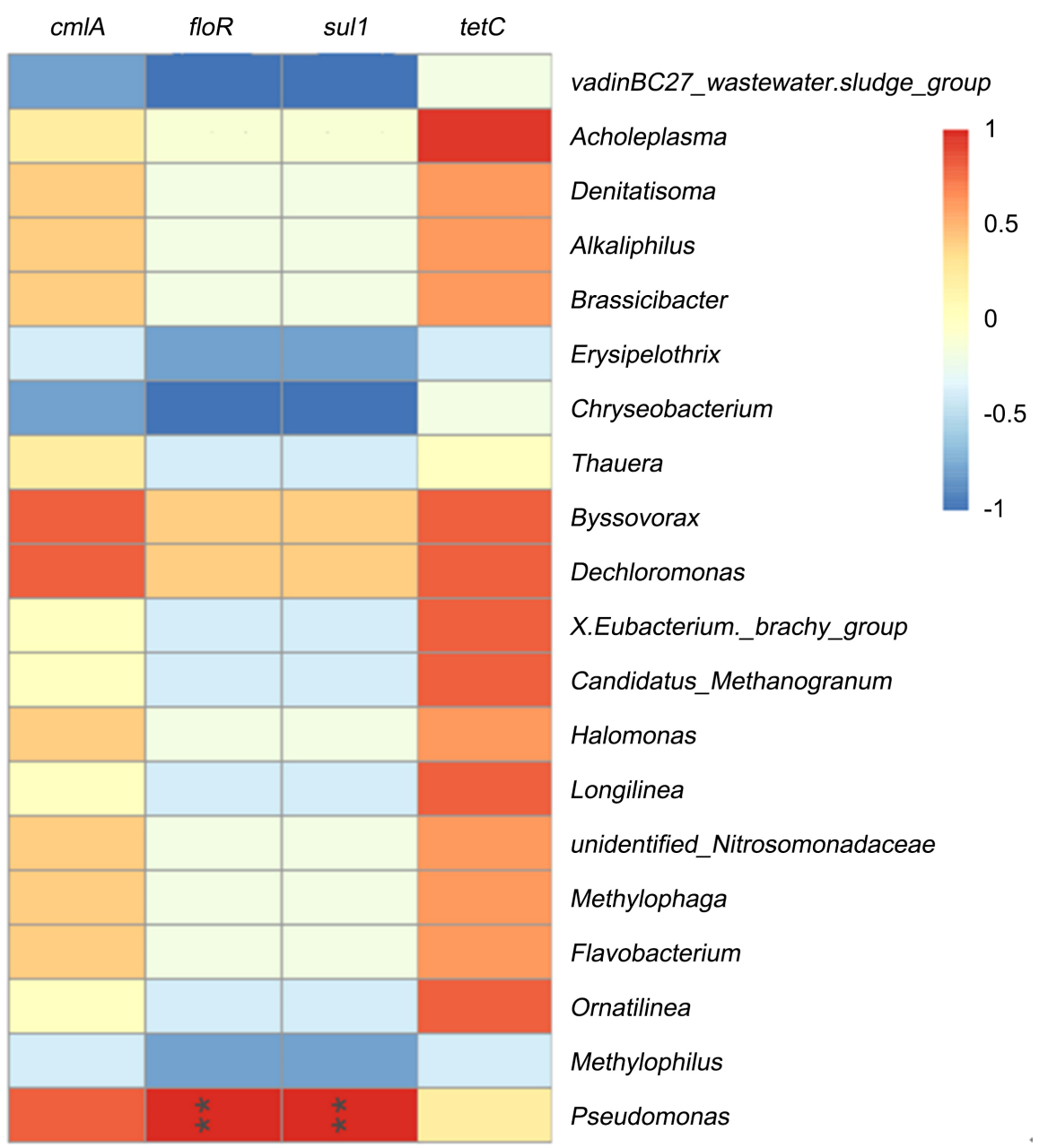

Figure 3. Quantitative correlation of the bacterial genera and ARGs in the samples collected from BESs under different salinities. The correlation analysis was performed using SPSS software, and the heatmap was drawn by $\mathrm{R}$ language. The scale bar shows the Spearman Indices (R). Red represents the positive correlation, and blue represents the negative correlation. An asterisk $\left(^{*}\right)$ indicates Significant Correlation $(P<0.05)$, and two asterisks $\left({ }^{*}\right)$ indicate Extreme Significant Correlation $(P<0.01)$ [83]. 


\section{Dares and Prospects for Bioelectrochemical Systems (BESs)}

By merging microbial metabolism and EC redox reduction, BESs are adopted as an emerging environment-benign and encouraging handling for emerging contaminants, particularly antibiotics. Yan et al. [84] discussed the impact of different environmental agents on the BESs' efficiency, functional microbes, and ARGs. Nevertheless, the present pieces of literature mostly focused on searching functional bacteria but not further to discover the biocatalyst pathway about functional genes. Further, numerous researches were dedicated to examining the elimination potential of conventional BESs for wastewater carrying antibiotics but not participate in developing BESs to deal with antibiotics contaminants concentrated in solid matrixes. Consequently, taking into account the diversity of antibiotic contaminants and the complexity of realistic pollutant environments, numerous dares in terms of the amelioration of the elimination capability, a revelation of biocatalyst pathway, development of BESs, and ARGs research stay to be addressed and require more focus (Table 2).

\section{Conclusions}

This work discussed the inactivation of ARB and ARGs by EC oxidation/electroFenton process and compared electro-Fenton and photo Fenton like process $\mathrm{UV}-\mathrm{C} / \mathrm{H} 2 \mathrm{O} 2 / \mathrm{IDS}-\mathrm{Cu}$ method with other AOPs techniques. A special focus is accorded to decreased Klebsiella michiganensis strain LH-2 viability and corresponding ARG abundance in bioelectrochemical reactors and the fate of ARGs during bioelectrochemical treatment of high-salinity pharmaceutical wastewater. Dares and prospects for bioelectrochemical systems (BESs) are suggested. The main points drawn from this work are listed below:

1) The $\mathrm{CA}$ and $\mathrm{Cu}^{2+}$ removal ability of a BES was studied and the fate of the ARGs (cmlA, floR, tetC, and sul1) and intIl was followed [112], and the bacterial community's structure when the cathode was exposed to different initial concentrations of $\mathrm{Cu}^{2+}$. The efficiency of the BES for CAP removal was inhibited when $\mathrm{Cu}^{2+}$ and CAP coexisted and the inhibition effect increased with increasing $\mathrm{Cu}^{2+}$ concentration. Further, the various concentrations of $\mathrm{Cu}^{2+}$ dramatically changed the relative abundances of the ARGs and the bacterial community structure in the BES. The shift of the potential host bacteria mainly contributed to the changes in the ARGs (except for sul1).

2) Laboratory-scale EC disinfection tests were performed to examine its reduction performance for 23 ARGs that confer against eight classes of antibiotics and its effects on the antibiotic resistance of surviving bacteria [113]. EC treatments were realized at varying current densities ( $D$ treatment) and with different reaction times ( $T$ treatment). Prolonged electrolysis conducted to a higher demobilization rate than an augmented current density, while the former was less efficient in the removal of ARGs. As an illustration, the demobilization ratios for the T20 and D80 treatments were both $>99 \%$, while the decrease in the relative 
Table 2. Dares and prospects for bioelectrochemical systems (BESs) [84].

\begin{tabular}{|c|c|}
\hline Dares and prospects & Description \\
\hline $\begin{array}{c}\text { Capacity } \\
\text { improvement }\end{array}$ & $\begin{array}{l}\text { Despite the main signs of progress, the elimination potentials of antibiotics in BESs are comparatively low taking } \\
\text { into account their future utilization in realistic polluted waters. Enhancing the electron transfer capability remains } \\
\text { crucial to deal with such trouble [85] [86] [87]. Electrodes are the habitats of exoelectrogens and dictate the activity } \\
\text { of microorganisms and the global efficiency of BESs [88] [89] [90]. Consequently, low-cost and durable electrode } \\
\text { materials with superior conductivity and biocompatibility remain to be sophisticated [91] [92] [93]. Biochar and its } \\
\text { modification materials as well as other cost-effective carbon-based electrodes could be excellent solutions [94] [95] [96]. } \\
\text { Juxtaposing diverse electrodes in terms of their impact on microbial community and electron transfer has to be } \\
\text { examined in the next years [97] [98] [99]. Moreover, adding electron transfer mediators could increase the } \\
\text { elimination capability, and the interplay of electrochemically active microbes, electrodes, and electron } \\
\text { transfer mediators warrants further studies [100] [101] [102]. }\end{array}$ \\
\hline $\begin{array}{l}\text { Biocatalyst } \\
\text { mechanism }\end{array}$ & $\begin{array}{l}\text { The functional species matching with numerous representative antibiotics were well illustrated by Yan et al. [84]. } \\
\text { However, the pathway implied in the electron transfer between pathogens and electrodes and among mixed bacteria } \\
\text { stays vague and the metabolic mechanisms of functional genes for antibiotics detoxification request to be illustrated } \\
\text { in the next years [103] [104] [105]. Omics techniques, like metagenomics, metaproteomics, and metabolomics, } \\
\text { might be conducive for the exploration of functional genes concerning the electron transfer and metabolic routes } \\
\text { of antibiotics to reveal the potential proteins mediating electron transport and to define the potential enzymes } \\
\text { catalyzing metabolic reactions of antibiotics. Further, how to efficaciously dominate the generation of functional } \\
\text { biofilms and to improve the expression of relevant functional genes under various working factors have to } \\
\text { attract more attention in the next studies. }\end{array}$ \\
\hline ARG investigation & $\begin{array}{l}\text { Considering the diversity of ARGs and the difference of ecological parameters of diverse ARGs, more examinations } \\
\text { of more types of ARGs and their interaction in BESs are needed [106] [107] [108]. High-throughput quantitative } \\
\text { polymerase chain reaction (PCR) stays a powerful procedure that could be employed to simultaneously quantify } \\
\text { nearly } 300 \text { types of ARGs [109] [110] [111]. Further, functional metagenomics possess an essential contribution } \\
\text { in detecting obscure ARGs. Consequently, high-throughput quantitative PCR and functional metagenomics are } \\
\text { predictable to light scientific troubles about biofilms in BESs comprising the abundance and diversity of ARGs, } \\
\text { route of horizontal gene transfer, and dissimilarities of ARG expression under single and multi-antibiotics during } \\
\text { long-term operation. The co-existence of antibiotics and additional emerging contaminants (like pharmaceuticals } \\
\text { and personal care products) should be noticed in the realistic environment. As a result, besides the feasibility of } \\
\text { BESs for eliminating co-existent contaminants, the influence of co-existent contaminants on ARGs in } \\
\text { electroactive biofilms should be considered. }\end{array}$ \\
\hline $\begin{array}{c}\text { System } \\
\text { development }\end{array}$ & $\begin{array}{l}\text { Numerous investigations were realized in simulative aquatic mediums; however, the emerging contaminants of } \\
\text { antibiotics are omnipresent and frequently established to be readily concentrated in solid matrixes (like sediments, } \\
\text { sludge, and soil). The development of sediment MFCs and plant MFCs or other solid BESs might be an important } \\
\text { basis to examine such problems. Specific BESs remain to be suggested for numerous surroundings implying the } \\
\text { study of the elimination capability and crucial parameters of antibiotics-containing solid matrixes. Furthermore, } \\
\text { the coexistence of antibiotics pollutants and other contaminants (like heavy metals) is pandemic. Heavy metals } \\
\text { pose a co-selective pressure on ARGs. Biocathodes have proven to be a good platform for the reduction of metals } \\
\text { and antibiotics. Thus, it requires to be examined if biocathodes are a good choice for the treatment of matrixes } \\
\text { carrying both antibiotic pollutants and heavy metals and for the release of the co-selective pressure through } \\
\text { a rapid transformation. }\end{array}$ \\
\hline
\end{tabular}

abundance of ARGs with D80 (from 0.54 to 4.1) was greater than that with T20 (from 5.4 to 5.2). The detection frequency of bacteria resistant to the tested antibiotics decreased by $9 \%-100 \%$ after EC treatment. This was mainly attributed to a change in bacterial composition. The proportion of bacteria with high antibiotic resistance frequencies decreased (like Escherichia), while that with low resistance frequencies (such as Acinetobacter and Pseudomonas) increased. Further, fewer multi-antibiotic-resistant bacteria survived EC disinfection, which 
also contributed to the significant decrease in the frequency of ARB as well as in the multi-antibiotic-resistance indices of wastewater samples (from 0.47 to 0.35 ) after EC treatment $(\mathrm{P}<0.05)$. In total, EC disinfection not only reduced the relative abundance of ARGs but also impaired the antibiotic resistance of surviving bacteria. Therefore, it might be a promising disinfection method for controlling the dissemination of antibiotic resistance.

3) For removing antibiotics, BES has numerous advantages and disadvantages [114]. The efficient removal of antibiotics occurs mainly due to faster oxidation through co metabolic degradation or direct oxidation by the anode in which the antibiotic is served as a sole electron donor in microbial fuel cells (MFCs). For the microbial electrolysis cells (MECs), a cathode can provide continuous electrons for the reduction of antibiotics. The most abundant phylum in BES is Proteobacteria. Antibiotics and electric current affect the microbial communities and their relative abundances. Antibiotics can be used as the sole carbon source for electricity generation in MFCs, but antibiotics could inhibit the electricity-generating activity of the microbial community. Therefore, the relationship between antibiotics and electricity generation requires further investigation. In addition, a low electric current could promote ARG transfer through vertical gene transfer (VGT) and horizontal gene transfer (HGT) during antibiotic degradation in BES. ARB and ARGs are eliminated with the high electric current. Questions regarding the potential role of BES for antibiotic removal and the reduction of ARGs and ARB are raised [115] [116] [117]. Further research is needed to elucidate the primary ARG transfer mechanism and to fully understand the advantages of BESs.

\section{Acknowledgements}

The Research Deanship of University of Ha'il, Saudi Arabia, through the Project RG-191190, has funded this research.

\section{Conflicts of Interest}

The author declares no conflicts of interest regarding the publication of this paper.

\section{References}

[1] He, P.J., Zhou, Y.Z., Shao, L.M., Huang, J.H., Yang, Z. and Lü, F. (2019) The Discrepant Mobility of Antibiotic Resistant Genes: Evidence from Their Spatial Distribution in Sewage Sludge Flocs. Science of the Total Environment, 697, Article ID: 134176. https://doi.org/10.1016/j.scitotenv.2019.134176

[2] Li, H.N., Li, B.X., Ma, J.L., Ye, J., Guo, P. and Li, L.F. (2018) Fate of Antibiotic-Resistant Bacteria and Antibiotic Resistance Genes in the Electrokinetic Treatment of Antibiotic-Polluted Soil. Chemical Engineering Journal, 337, 584-594. https://doi.org/10.1016/j.cej.2017.12.154

[3] Chen, L., Zhou, Z., Shen, C.F. and Xu, Y.L. (2020) Inactivation of Antibiotic-Resistant Bacteria and Antibiotic Resistance Genes (ARGs) by Electrochemical 
Oxidation/Electro-Fenton Process. Water Science \& Technology, 81, 2221-2231.

[4] Auguet, O., Pijuan, M., Borrego, C.M., Rodriguez-Mozaz, S., Triadó-Margarit, X., Giustina, S.V.D. and Gutierrez, O. (2017) Sewers as Potential Reservoirs of Antibiotic Resistance. Science of the Total Environment, 605-606, 1047-1054.

https://doi.org/10.1016/j.scitotenv.2017.06.153

[5] Qiao, M., Ying, G.G., Singer, A.C. and Zhu, Y.Z. (2018) Review of Antibiotic Resistance in China and Its Environment. Environment International, 110, 160-172. https://doi.org/10.1016/j.envint.2017.10.016

[6] Cheng, J., Tang, X. and Cui, J. (2019) Effect of Long-Term Manure Slurry Application on the Occurrence of Antibiotic Resistance Genes in Arable Purple Soil (Entisol). Science of the Total Environment, 647, 853-861. https://doi.org/10.1016/j.scitotenv.2018.08.028

[7] Vikesland, P.J., Pruden, A., Alvarez, P.J.J., Aga, D., Bürgmann, H., Li, X.D., Manaia, C.M., Nambi, I., Wigginton, K., Zhang, T. and Zhu, Y.G. (2017) Towards a Comprehensive Strategy to Mitigate Dissemination of Environmental Sources of Antibiotic Resistance. Environmental Science \& Technology, 51, 13061-13069. https://doi.org/10.1021/acs.est.7b03623

[8] Ghernaout, D. and Elboughdiri, N. (2020) Should We Forbid the Consumption of Antibiotics to Stop the Spread of Resistances in Nature? Open Access Library Journal, 7, e6138.

[9] Ghernaout, D. and Elboughdiri, N. (2020) Antibiotics Resistance in Water Mediums: Background, Facts, and Trends. Applied Engineering, 4, 1-6.

[10] Ghernaout, D. and Elboughdiri, N. (2020) Removing Antibiotic-Resistant Bacteria (ARB) Carrying Genes (ARGs): Challenges and Futuretrends. Open Access Library Journal, 7, e6003. https://doi.org/10.4236/oalib.1106003

[11] Sharma, V.K., Johnson, N., Cizmas, L., Mcdonald, T.J. and Kim, H. (2016) A Review of the Influence of Treatment Strategies on Antibiotic Resistant Bacteria and Antibiotic Resistance Genes. Chemosphere, 150, 702-714.

https://doi.org/10.1016/j.chemosphere.2015.12.084

[12] Dodd, M.C. (2012) Potential Impacts of Disinfection Processes on Elimination and Deactivation of Antibiotic Resistance Genes during Water and Wastewater Treatment. Journal of Environmental Monitoring, 14, 1754-1771. https://doi.org/10.1039/c2em00006g

[13] Pruden, A. (2014) Balancing Water Sustainability and Public Health Goals in the Face of Growing Concerns about Antibiotic Resistance. Environmental Science \& Technology, 48, 5-14. https://doi.org/10.1021/es403883p

[14] Ghernaout, D., Alshammari, Y. and Alghamdi, A. (2018) Improving Energetically Operational Procedures in Wastewater Treatment Plants. International Journal of Advanced and Applied Sciences, 5, 64-72. https://doi.org/10.21833/ijaas.2018.09.010

[15] Alshammari, Y., Ghernaout, D., Aichouni, M. and Touahmia, M. (2018) Improving Operational Procedures in Riyadh's (Saudi Arabia) Water Treatment Plants Using Quality Tools. Applied Engineering, 2, 60-71.

[16] Ghernaout, D., Naceur, M.W. and Aouabed, A. (2011) On the Dependence of Chlorine By-Products Generated Species Formation of the Electrode Material and Applied Charge during Electrochemical Water Treatment. Desalination, 270, 9-22. https://doi.org/10.1016/j.desal.2011.01.010

[17] Ghernaout, D., Moulay, S., Ait Messaoudene, N., Aichouni, M., Naceur, M.W. and Boucherit, A. (2014) Coagulation and Chlorination of NOM and Algae in Water 
Treatment: A Review. International Journal of Environmental Monitoring and Analysis, 2, 23-34.

[18] Ghernaout, D. (2017) Water Treatment Chlorination: An Updated Mechanistic Insight Review. Chemistry Research Journal, 2, 125-138.

[19] Ghernaout, D. and Elboughdiri, N. (2020) UV-C/ $\mathrm{H}_{2} \mathrm{O}_{2}$ and Sunlight $/ \mathrm{H}_{2} \mathrm{O}_{2}$ in the Core of the Best Available Technologies for Dealing with Present Dares in Domestic Wastewater Reuse. Open Access Library Journal, 7, e6161. https://doi.org/10.4236/oalib.1106161

[20] Ghernaout, D. and Elboughdiri, N. (2020) Vacuum-UV Radiation at $185 \mathrm{Nm}$ for Disinfecting Water. Chemical Science \& Engineering Research, 2, 12-17.

[21] Ghernaout, D. and Elboughdiri, N. (2020) Urgent Proposals for Disinfecting Hospital Wastewaters during COVID-19 Pandemic. Open Access Library Journal, 7, e6373. https://doi.org/10.4236/oalib.1106373

[22] Ghernaout, D. and Elboughdiri, N. (2020) Towards Enhancing Ozone Diffusion for Water Disinfection-Short Notes. Open Access Library Journal, 7, e6253.

[23] Ghernaout, D. and Ghernaout, B. (2020) Controlling COVID-19 Pandemic through Wastewater Monitoring. Open Access Library Journal, 7, e6411. https://doi.org/10.4236/oalib.1106411

[24] Ghernaout, D. (2013) The Best Available Technology of Water/Wastewater Treatment and Seawater Desalination: Simulation of the Open Sky Seawater Distillation. Green Sustain. Green and Sustainable Chemistry, 3, 68-88. https://doi.org/10.4236/gsc.2013.32012

[25] Ghernaout, D. (2018) Increasing Trends towards Drinking Water Reclamation from Treated Wastewater. World Journal of Applied Chemistry, 3, 1-9. https://doi.org/10.11648/j.wjac.20180301.11

[26] Ghernaout, D. and Ghernaout, B. (2010) From Chemical Disinfection to Electrodisinfection: The Obligatory Itinerary? Desalination and Water Treatment, 16, 156-175. https://doi.org/10.5004/dwt.2010.1085

[27] Ghernaout, D. (2018) Disinfection and DBPs Removal in Drinking Water Treatment: A Perspective for a Green Technology. International Journal of Advanced and Applied Sciences, 5, 108-117. https://doi.org/10.21833/ijaas.2018.02.018

[28] Ghernaout, D., Touahmia, M. and Aichouni, M. (2019) Disinfecting Water: Electrocoagulation as an Efficient Process. Applied Engineering, 3, 1-12.

[29] Ghernaout, D., Aichouni, M. and Touahmia, M. (2019) Mechanistic Insight into Disinfection by Electrocoagulation-A Review. Desalination and Water Treatment, 141, 68-81. https://doi.org/10.5004/dwt.2019.23457

[30] Ghernaout, D. (2019) Greening Electrocoagulation Process for Disinfecting Water. Applied Engineering, 3, 27-31.

[31] Ghernaout, D. (2019) Electrocoagulation and Electrooxidation for Disinfecting Water: New Breakthroughs and Implied Mechanisms. Applied Engineering, 3, 125-133.

[32] Czekalski, N., Imminger, S., Salhi, E., Veljkovic, M., Kleffe, K. and Drissner, D. (2016) Inactivation of Antibiotic Resistant Bacteria and Resistance Genes by Ozone: from Laboratory Experiments to Full-Scale Wastewater Treatment, Environmental Science \& Technology, 50, 11862-11871.

[33] Ghernaout, D. and Elboughdiri, N. (2019) Electrocoagulation Process intensification for Disinfecting Water-A Review. Applied Engineering, 3, 140-147.

[34] Ghernaout, D. and Elboughdiri, N. (2019) Iron Electrocoagulation Process for Dis- 
infecting Water-A Review. Applied Engineering, 3, 154-158.

[35] Ghernaout, D. (2019) Disinfection via Electrocoagulation Process: Implied Mechanisms and Future Tendencies. EC Microbiology, 15, 79-90.

[36] Ghernaout, D. and Elboughdiri, N. (2019) Mechanistic Insight into Disinfection Using Ferrate(VI). Open Access Library Journal, 6, e5946. https://doi.org/10.4236/oalib.1105946

[37] Ghernaout, D. and Elboughdiri, N. (2019) Water Disinfection: Ferrate(VI) as the Greenest Chemical-A Review. Applied Engineering, 3, 171-180.

[38] Al Arni, S., Amous, J. and Ghernaout, D. (2019) On the Perspective of Applying of a New Method for Wastewater Treatment Technology: Modification of the Third Traditional Stage with Two Units, one by Cultivating Microalgae and Another by Solar Vaporization. International Journal of Environmental Sciences \& Natural Resources, 16, Article ID: 555934. https://doi.org/10.19080/IJESNR.2019.16.555934

[39] Ghernaout, D., Elboughdiri, N. and Al Arni, S. (2019) Water Reuse (WR): Dares, Restrictions, and Trends. Applied Engineering, 3, 159-170.

[40] Ghernaout, D., Elboughdiri, N. and Ghareba, S. (2019) Drinking Water Reuse: OneStep Closer to Overpassing the "Yuck Factor". Open Access Library Journal, 6, e5895. https://doi.org/10.4236/oalib.1105895

[41] Ghernaout, D. and Elboughdiri, N. (2020) Advanced Oxidation Processes for Wastewater Treatment: Facts and Future Trends. Open Access Library Journal, 7, e6139. https://doi.org/10.4236/oalib.1106139

[42] Ghernaout, D., Elboughdiri, N., Ghareba, S. and Salih, A. (2020) Electrochemical Advanced Oxidation Processes (EAOPs) for Disinfecting Water-Fresh Perspectives. Open Access Library Journal, 7, e6257. https://doi.org/10.4236/oalib.1106257

[43] Ghernaout, D. (2013) Advanced Oxidation Phenomena in Electrocoagulation Process: A Myth or a Reality? Desalination and Water Treatment, 51, 7536-7554. https://doi.org/10.1080/19443994.2013.792520

[44] Zhang, Y., Zhuang, Y., Geng, J., Ren, H., Zhang, Y., Ding, L. and Xu, K. (2015) Inactivation of Antibiotic Resistance Genes in Municipal Wastewater Effluent by Chlorination and Sequential UV/Chlorination Disinfection. Science of the Total Environment, 512-513, 125-132. https://doi.org/10.1016/j.scitotenv.2015.01.028

[45] Ghernaout, D., Alghamdi, A., Aichouni, M. and Touahmia, M. (2018) The Lethal Water Tri-Therapy: Chlorine, Alum, and Polyelectrolyte. World Journal of Applied Chemistry, 3, 65-71. https://doi.org/10.11648/j.wjac.20180302.14

[46] Ghernaout, D. and Elboughdiri, N. (2020) Is Not It Time To Stop Using Chlorine for Treating Water? Open Access Library Journal, 7, e6007.

[47] Boucherit, A., Moulay, S., Ghernaout, D., Al-Ghonamy, A.I., Ghernaout, B., Naceur, M.W., Ait Messaoudene, N., Aichouni, M., Mahjoubi, A.A. and Elboughdiri, N.A. (2015) New Trends in Disinfection By-Products Formation upon Water Treatment. Journal of Research \& Developments in Chemistry, 2015, Article ID: 628833.

[48] Oh, J., Medriano, C.A. and Kim, S. (2016) The Effect of Tetracycline in the Antibiotic Resistance Gene Transfer before and after Ozone Disinfection. Desalination and Water Treatment, 57, 646-650. https://doi.org/10.1080/19443994.2014.986828

[49] Zheng, J., Su, C., Zhou, J.W., Xu, K., Qian, Y.Y. and Chen, H. (2017) Effects and Mechanisms of Ultraviolet, Chlorination, and Ozone Disinfection on Antibiotic Resistance Genes in Secondary Effluents of Municipal Wastewater Treatment Plants. Chemical Engineering Journal, 317, 309-316.

https://doi.org/10.1016/j.cej.2017.02.076 
[50] Guo, M.T., Yuan, Q.B. and Yang, J. (2015) Distinguishing Effects of Ultraviolet Exposure and Chlorination on the Horizontal Transfer of Antibiotic Resistance Genes in Municipal Wastewater. Environmental Science \& Technology, 49, 5771-5778. https://doi.org/10.1021/acs.est.5b00644

[51] Huang, X., Liu, C.X., Li, K., Su, J.Q., Zhu, G.F. and Liu, L. (2015) Performance of Vertical Up-Flow Constructed Wetlands on Swine Wastewater Containing Tetracyclines and Tet Genes. Water Research, 70, 109-117.

https://doi.org/10.1016/j.watres.2014.11.048

[52] Ghernaout, D. and Elboughdiri, N. (2020) Strategies for Reducing Disinfection By-Products Formation during Electrocoagulation. Open Access Library Journal, 7, e6076. https://doi.org/10.4236/oalib.1106076

[53] Ghernaout, D. and Elboughdiri, N. (2020) Electrocoagulation Process in the Context of Disinfection Mechanism, Open Access Library Journal, 7, e6083.

[54] Ghernaout, D. and Elboughdiri, N. (2020) Disinfection by-Products: Presence and Elimination in Drinking Water. Open Access Library Journal, 7, e6140.

https://doi.org/10.4236/oalib.1106140

[55] Ghernaout, D. and Elboughdiri, N. (2020) Controlling Disinfection By-Products Formation in Rainwater: Technologies and Trends. Open Access Library Journal, 7, e6162. https://doi.org/10.4236/oalib.1106162

[56] Ghernaout, D., Elboughdiri, N., Ghareba, S. and Salih, A. (2020) Disinfecting Water with the Carbon Fiber-Based Flow-through Electrode System (FES): towards Axial Dispersion and Velocity Profile. Open Access Library Journal, 7, e6238.

https://doi.org/10.4236/oalib.1106238

[57] Ghernaout, D., Elboughdiri, N. and Ghareba, S. (2020) Fenton Technology for Wastewater Treatment: Dares and Trends. Open Access Library Journal, 7, e6045. https://doi.org/10.4236/oalib.1106045

[58] Zhang, Y., Yao, Z., Geng, J., Ren, H., Xu, K. and Ding, L. (2016) Reduction of Antibiotic Resistance Genes in Municipal Wastewater Effluent by Advanced Oxidation Processes. Science of the Total Environment, 50, 184-191.

https://doi.org/10.1016/j.scitotenv.2016.01.078

[59] Yoon, Y., Chung, H.J., Wen, D.D., Dodd, M.C., Hur, H.G. and Lee, Y. (2017) Inactivation Efficiency of Plasmid-Encoded Antibiotic Resistance Genes during Water Treatment with Chlorine, UV, and $\mathrm{UV} / \mathrm{H}_{2} \mathrm{O}_{2}$. Water Research, 123, 783-793. https://doi.org/10.1016/j.watres.2017.06.056

[60] Guo, C.S., Wang, K., Hou, S., Wan, L., Lv, J.P., Zhang, Y., Qu, X.D., Chen, S.Y. and $\mathrm{Xu}$, J. (2017) $\mathrm{H}_{2} \mathrm{O}_{2}$ and/Or $\mathrm{TiO}_{2}$ Photocatalysis under UV Irradiation for the Removal of Antibiotic Resistant Bacteria and Their Antibiotic Resistance Genes. Journal of Hazardous Materials, 323, 710-718.

https://doi.org/10.1016/j.jhazmat.2016.10.041

[61] Ghernaout, D., Elboughdiri, N., Alghamdi, A. and Ghernaout, B. (2020) Trends in Decreasing Disinfection By-Products Formation during Electrochemical Technologies. Open Access Library Journal, 7, e6337. https://doi.org/10.4236/oalib.1106337

[62] Ghernaout, D. and Elboughdiri, N. (2020) Foresight Look on the Disinfection By-Products Formation, Open Access Library Journal, 7, e6349.

[63] Ghernaout, D. and Elboughdiri, N. (2020) Solar Treatment in the Core of the New Disinfection Technologies. Chemical Science \& Engineering Research, 2, 6-11.

[64] Ghernaout, D. and Elboughdiri, N. (2020) Disinfection By-Products Regulation: Zero ng/L Target. Open Access Library Journal, 7, e6382. 
https://doi.org/10.4236/oalib.1106382

[65] Ghernaout, D. and Elboughdiri, N. (2020) Disinfection By-Products (DBPs) Control Strategies in Electrodisinfection. Open Access Library Journal, 7, e6396.

[66] Ghernaout, D. and Elboughdiri, N. (2020) On the Other Side of Viruses in the Background of Water Disinfection. Open Access Library Journal, 7, e6374. https://doi.org/10.4236/oalib.1106374

[67] Ghernaout, D., Badis, A., Ghernaout, B. and Kellil, A. (2008) Application of Electrocoagulation in Escherichia coli Culture and Two Surface Waters. Desalination, 219, 118-125. https://doi.org/10.1016/j.desal.2007.05.010

[68] Ghernaout, D. (2017) Microorganisms' Electrochemical Disinfection Phenomena. EC Microbiology, 9, 160-169.

[69] Ghernaout, D., Alghamdi, A. and Ghernaout, B. (2019) Microorganisms' Killing: Chemical Disinfection vs. Electrodisinfection. Applied Engineering, 3, 13-19.

[70] Ghernaout, D. (2019) Virus Removal by Electrocoagulation and Electrooxidation: New Findings and Future Trends. Journal of Environmental Science and Allied Research, 85-90. https://doi.org/10.29199/2637-7063/ESAR-202024

[71] Ghernaout, D. and Elboughdiri, N. (2020) Environmental Engineering for Stopping Viruses Pandemics. Open Access Library Journal, 7, e6299.

[72] Ghernaout, D. and Elboughdiri, N. (2020) Disinfecting Water: Plasma Discharge for Removing Coronaviruses. Open Access Library Journal, 7, e6314. https://doi.org/10.4236/oalib.1106314

[73] Ghernaout, D., Benblidia, C. and Khemici, F. (2015) Microalgae Removal from Ghrib Dam (Ain Defla, Algeria) Water by Electroflotation Using Stainless Steel Electrodes. Desalination and Water Treatment, 54, 3328-3337. https://doi.org/10.1080/19443994.2014.907749

[74] Ghernaout, D. (2019) Electrocoagulation Process for Microalgal Biotechnology-A Review. Applied Engineering, 3, 85-94.

[75] Rahmani, A.R., Samarghandi, M.R., Nematollahi, D. and Zamani, F. (2019) A Comprehensive Study of Electrochemical Disinfection of Water Using Direct and Indirect Oxidation Processes. Journal of Environmental Chemical Engineering, 7, Article ID: 102785. https://doi.org/10.1016/j.jece.2018.11.030

[76] Ghernaout, D. (2020) Electric Field (EF) in the Core of the Electrochemical (EC) Disinfection. Open Access Library Journal, 7, e6587. https://doi.org/10.4236/oalib.1106587

[77] Ghernaout, D. (2020) Water Treatment Challenges towards Viruses Removal. Open Access Library Journal, 7, e6408. https://doi.org/10.4236/oalib.1106408

[78] Di Cesare, A., De Carluccio, M., Eckert, E.M., Fontaneto, D., Fiorentino, A., Corno, G., Prete, P., Cucciniello, R., Proto, A. and Rizzo, L. (2020) Combination of Flow Cytometry and Molecular Analysis to Monitor the Effect of $\mathrm{UVC} / \mathrm{H}_{2} \mathrm{O}_{2}$ Vs $\mathrm{UVC} / \mathrm{H}_{2} \mathrm{O}_{2} / \mathrm{Cu}$-IDS Processes on Pathogens and Antibiotic Resistant Genes in Secondary Wastewater Effluents. Water Research, 184, Article ID: 116194. https://doi.org/10.1016/j.watres.2020.116194

[79] Li, H., Zhang, S., Yang, X.-L., Xu, H., Yang, Y.-L., Wang, Y.-W. and Song, H.-L. (2018) Simulated Wastewater Reduced Klebsiella michiganensis Strain LH-2 Viability and Corresponding Antibiotic Resistance Gene Abundance in Bio-Electrochemical Reactors. Ecotoxicology and Environmental Safety, 162, 376-382. https://doi.org/10.1016/j.ecoenv.2018.07.018

[80] Ghernaout, D. (2020) New Configurations and Techniques for Controlling Mem- 
brane Bioreactor (MBR) Fouling. Open Access Library Journal, 7, e6579.

[81] Ghernaout, D. (2019) Reviviscence of Biological Wastewater Treatment-A Review, Applied Engineering, 3, 46-55.

[82] Ghernaout, D. and Elboughdiri, N. (2019) Upgrading Wastewater Treatment Plant to Obtain Drinking Water. Open Access Library Journal, 6, e5959. https://doi.org/10.4236/oalib.1105959

[83] Guo, N., Wang, Y., Tong, T. and Wang, S. (2018) The Fate of Antibiotic Resistance Genes and Their Potential Hosts during Bio-Electrochemical Treatment of HighSalinity Pharmaceutical Wastewater. Water Research, 133, 79-86. https://doi.org/10.1016/j.watres.2018.01.020

[84] Yan, W., Xiao, Y., Yan, W., Ding, R., Wang, S. and Zhao, F. (2019) The Effect of Bioelectrochemical Systems on Antibiotics Removal and Antibiotic Resistance Genes: A Review. Chemical Engineering Journal, 358, 1421-1437. https://doi.org/10.1016/j.cej.2018.10.128

[85] Ghernaout, D., Ghernaout, B., Saiba, A., Boucherit, A. and, Kellil, A. (2009) Removal of Humic Acids by Continuous Electromagnetic Treatment Followed by Electrocoagulation in Batch Using Aluminium Electrodes. Desalination, 239, 295-308. https://doi.org/10.1016/j.desal.2008.04.001

[86] Ghernaout, D., Ghernaout, B. and Boucherit, A. (2008) Effect of pH on Electrocoagulation of Bentonite Suspensions in Batch Using Iron Electrodes. Journal of Dispersion Science and Technology, 29, 1272-1275. https://doi.org/10.1080/01932690701857483

[87] Ghernaout, D., Ghernaout, B. and Kellil, A. (2009) Natural Organic Matter Removal and Enhanced Coagulation as a Link between Coagulation and Electrocoagulation, Desalination and Water Treatment, 2, 203-222. https://doi.org/10.5004/dwt.2009.116

[88] Ghernaout, D., Ghernaout, B., Boucherit, A., Naceur, M.W., Khelifa, A. and Kellil, A. (2009) Study on Mechanism of Electrocoagulation with Iron Electrodes in Idealised Conditions and Electrocoagulation of Humic Acids Solution in Batch Using Aluminium Electrodes. Desalination and Water Treatment, 8, 91-99. https://doi.org/10.5004/dwt.2009.668

[89] Saiba, A., Kourdali, S., Ghernaout, B. and Ghernaout, D. (2010) In Desalination, from 1987 to 2009, the Birth of a New Seawater Pretreatment Process: Electrocoagulation-An Overview. Desalination and Water Treatment, 16, 201-217. https://doi.org/10.5004/dwt.2010.1094

[90] Belhout, D., Ghernaout, D., Djezzar-Douakh, S. and Kellil, A. (2010) Electrocoagulation of a Raw Water of Ghrib Dam (Algeria) in Batch Using Iron Electrodes. Desalination and Water Treatment, 16, 1-9. https://doi.org/10.5004/dwt.2010.1081

[91] Ghernaout, D., Mariche, A., Ghernaout, B. and Kellil, A. (2010) Electromagnetic Treatment-Bi-Electrocoagulation of Humic Acid in Continuous Mode Using Response Surface Method for Its Optimization and Application on Two Surface Waters. Desalination and Water Treatment, 22, 311-329.

https://doi.org/10.5004/dwt.2010.1120

[92] Ghernaout, D. and Ghernaout, B. (2011) On the Controversial Effect of Sodium Sulphate as Supporting Electrolyte on Electrocoagulation Process: A Review. Desalination and Water Treatment, 27, 243-254. https://doi.org/10.5004/dwt.2011.1983

[93] Ghernaout, D., Ghernaout, B. and Naceur, M.W. (2011) Embodying the Chemical Water Treatment in the Green Chemistry-A Review. Desalination, 271, 1-10. https://doi.org/10.1016/j.desal.2011.01.032 
[94] Ghernaout, D., Naceur, M.W. and Ghernaout, B. (2011) A Review of Electrocoagulation as a Promising Coagulation Process for Improved Organic and inorganic Matters Removal by Electrophoresis and Electroflotation. Desalination and Water Treatment, 28, 287-320. https://doi.org/10.5004/dwt.2011.1493

[95] Ghernaout, D., Irki, S. and Boucherit, A. (2014) Removal of $\mathrm{Cu}^{2+}$ and $\mathrm{Cd}^{2+}$, and Humic Acid and Phenol by Electrocoagulation Using Iron Electrodes. Desalination and Water Treatment, 52, 3256-3270. https://doi.org/10.1080/19443994.2013.852484

[96] Ghernaout, D., Al-Ghonamy, A.I., Naceur, M.W., Ait Messaoudene, N. and Aichouni, M. (2014) Influence of Operating Parameters on Electrocoagulation of C.I. Disperse Yellow 3. Journal of Electrochemical Science and Engineering, 4, 271-283. https://doi.org/10.5599/jese.2014.0065

[97] Ghernaout, D., Al-Ghonamy, A.I., Irki, S., Grini, A., Naceur, M.W., Ait Messaoudene, N. and Aichouni, M. (2014) Decolourization of Bromophenol Blue by Electrocoagulation Process. Trends in Chemical Engineering, 15, 29-39.

[98] Ghernaout, D., Al-Ghonamy, A.I., Ait Messaoudene, N., Aichouni, M., Naceur, M.W., Benchelighem, F.Z. and Boucherit, A. (2015) Electrocoagulation of Direct Brown 2 (DB) and BF Cibacete Blue (CB) Using Aluminum Electrodes. Separation Science and Technology, 50, 1413-1420. https://doi.org/10.1080/01496395.2014.982763

[99] Irki, S., Ghernaout, D. and Naceur, M.W. (2017) Decolourization of Methyl Orange (MO) by Electrocoagulation (EC) Using Iron Electrodes under a Magnetic Field (MF). Desalination and Water Treatment, 79, 368-377. https://doi.org/10.5004/dwt.2017.20797

[100] Ghernaout, D. (2018) Electrocoagulation Process: Achievements and Green Perspectives. Colloid and Surface Science, 3, 1-5. https://doi.org/10.11648/j.css.20180301.11

[101] Ghernaout, D. (2008) Élimination des substances humiques et des germes indicateurs de contamination bactériologique par électrocoagulation assistée d'un traitement magnétique de l'eau. Ph.D. Thesis, University of Blida, Algeria.

[102] Irki, S., Ghernaout, D., Naceur, M.W., Alghamdi, A. and Aichouni, M. (2018) Decolorization of Methyl Orange (MO) by Electrocoagulation (EC) Using Iron Electrodes under a Magnetic Field (MF). II. Effect of Connection Mode. World Journal of Applied Chemistry, 3, 56-64. https://doi.org/10.11648/j.wjac.20180302.13

[103] Irki, S., Ghernaout, D., Naceur, M.W., Alghamdi, A. and Aichouni, M. (2018) Decolorizing Methyl Orange by Fe-Electrocoagulation Process-A Mechanistic Insight. International Journal of Environmental Chemistry, 2, 18-28.

https://doi.org/10.11648/j.ijec.20180201.14

[104] Ghernaout, D., Alghamdi, A. and Ghernaout, B. (2019) Electrocoagulation Process: A Mechanistic Review at the Dawn of Its Modeling. Journal of Environmental Science and Allied Research, 2, 51-67. https://doi.org/10.29199/2637-7063/ESAR-201019

[105] Ghernaout, D. and Elboughdiri, N. (2020) An Insight in Electrocoagulation Process through Current Density Distribution (CDD). Open Access Library Journal, 7, e6142.

[106] Ghernaout, D., Elboughdiri, N. and Alghamdi, A. (2019) Direct Potable Reuse: the Singapore NEWater Project as a Role Model. Open Access Library Journal, 6, e5980. https://doi.org/10.4236/oalib.1105980

[107] Ghernaout, D. and Elboughdiri, N. (2019) Water Reuse: Emerging Contaminants 
Elimination-Progress and Trends. Open Access Library Journal, 6, e5981. https://doi.org/10.4236/oalib.1105981

[108] Ghernaout, D. and Elboughdiri, N. (2020) Electrochemical Technology for Wastewater Treatment: Dares and Trends. Open Access Library Journal, 7, e6020. https://doi.org/10.4236/oalib.1106020

[109] Ghernaout, D. and Elboughdiri, N. (2020) On the Treatment Trains for Municipal Wastewater Reuse for Irrigation. Open Access Library Journal, 7, e6088. https://doi.org/10.4236/oalib.1106088

[110] Ghernaout, D. and Elboughdiri, N. (2020) Domestic Wastewater Treatment: Difficulties and Reasons, and Prospective Solutions-China as an Example. Open Access Library Journal, 7, e6141.

[111] Ghernaout, D. and Elboughdiri, N. (2020) Eliminating Cyanobacteria and Controlling Algal Organic Matter-Short Notes. Open Access Library Journal, 7, e6252. https://doi.org/10.4236/oalib.1106252

[112] Ma, X., Guo, N., Ren, S., Wang, S. and Wang, Y. (2019) Response of Antibiotic Resistance to the Co-Existence of Chloramphenicol and Copper during Bio-Electrochemical Treatment of Antibiotic-Containing Wastewater. Environment International, 126, 127-133. https://doi.org/10.1016/j.envint.2019.02.002

[113] Li, H., Zhang, Z., Duan, J., Li, N., Li, B., Song, T., Sardar, M.F., Lv, X. and Zhu, C. (2020) Electrochemical Disinfection of Secondary Effluent from a Wastewater Treatment Plant: Removal Efficiency of ARGs and Variation of Antibiotic Resistance in Surviving Bacteria. Chemical Engineering Journal, 392, Article ID: 123674. https://doi.org/10.1016/j.cej.2019.123674

[114] Zhang, S., Yang, Y.-L., Lu, J., Zuo, X.-J., Yang, X.-L. and Song, H.-L. (2020) A Review of Bioelectrochemical Systems for Antibiotic Removal: Efficient Antibiotic Removal and Dissemination of Antibiotic Resistance Genes. Journal of Water Process Engineering, 37, Article ID: 101421. https://doi.org/10.1016/j.jwpe.2020.101421

[115] Ghernaout, D. and Ghernaout, B. (2012) On the Concept of the Future Drinking Water Treatment Plant: Algae Harvesting from the Algal Biomass for Biodiesel Production-A Review. Desalination and Water Treatment, 49, 1-18. https://doi.org/10.1080/19443994.2012.708191

[116] Ghernaout, D. (2017) Water Reuse (WR): The Ultimate and Vital Solution for Water Supply Issues. International Journal of Sustainable Development Research, 3, 36-46. https://doi.org/10.11648/j.ijsdr.20170304.12

[117] Ghernaout, D. (2018) Magnetic Field Generation in the Water Treatment Perspectives: An Overview. International Journal of Advanced and Applied Sciences, 5, 193-203. https://doi.org/10.21833/ijaas.2018.01.025 